\title{
Methoxy- and Acetoxy-8-oxoberbines - Synthesis, Antitumor Activity, and Interaction with $\mathrm{DNA}^{*}$ )
}

\author{
Christian Weimar, Silvia von Angerer, and Wolfgang Wiegrebe \\ Institute of Pharmacy and Sonderforschungsbereich 234, University of Regensburg, Universitätsstr. 31, D-8400 Regensburg, Germany
}

Received July 6, 1990

\begin{abstract}
Most of the methoxy-8H-dibenzo[ $a, g]$ isoquinolin-8-ones 3a-h and their acetoxy derivatives 6a-e were synthesized by condensation of 1-oxo-1,2,3,4-tetrahydroisoquinolines $4 a-c$ and homophthalic acid anhydrides $5 \mathbf{a}$ and $\mathbf{b}$, ether cleavage and acetylation. These protoberberinones were tested for cytostatic activity in vitro using MDA-MB-231 mammary tumor cells and for interaction with native calf thymus DNA. Tetramethoxy-8-oxoberbine $3 f$ shows an inhibition of cell proliferation of $87 \%$ at a concentration of $10^{-5}$ mole; its cytostatic effect does not depend on intercalation into DNA.
\end{abstract}

Synthese, Antitumoraktivität und DNA-Interaktion von Methoxy- und Acetoxy-8-0xoberbinen

Die meisten der Methoxy-8H-dibenzo[a,g]chinolizin-8-one 3a-h und ihre Acetoxyderivate 6a-e wurden durch Kondensation der 1-Oxo-1,2,3,4-tetrahydroisochinoline 4a-c mit den Homophthalsäureanhydriden 5a und b, anschließende Etherspaltung und Acetylierung dargestellt. Die cytostatische Wirkung dieser Protoberberinone wurde an der MDA-MB-231-Zellinie, die DNA-Interaktion an nativer Kalbsthymus-DNA geprüft. Das Tetramethoxy8-oxoberbin $3 f$ zeigt eine Hemmung der Zellproliferation von $87 \%$ bei einer Konzentration von $10^{-5} \mathrm{M}$, wobei die cytostatische Wirkung nicht auf eine Interkalation mit der DNA zurückzuführen ist.
In 1972 Zee-Cheng ${ }^{1)}$ reported upon inhibitory effects of the alkaloid berberine (1, Fig. 1) in various models of leukaemia. This protoberberine derivative is nearly planar and characterized by a cationic center. These two properties might contribute to the affinity of berberine (1) to DNA and to its cytotoxic effect ${ }^{2}$. Berberine (1) and coralyne (2, Fig. 1) ${ }^{3)}$, however, proved to be too toxic for clinical use and so further development of this type of alkaloids is necessary.

Based on these findings, we describe the synthesis of methoxy- (type 3) and acetoxy-8-oxo-5,6-dihydro-dibenzo[a,g]quinolizines (type 6), their cytotoxic properties and their interaction with DNA.<smiles></smiles>

$\mathbf{R}^{1}+\mathbf{R}^{2}=-\mathrm{OCH}_{2} \mathrm{O}$ - Berberine chloride (1) $\mathbf{R}^{1}=\mathbf{R}^{2}=-\mathrm{OCH}_{3}$ Palmatine chloride (14)

Figure 1

\section{Chemistry}

The demand of a large variety of dihydro-dibenzo[ $a, g]$ quinolizin-8-ones (3) excludes many synthetic approaches ${ }^{4,5)}$ and led us to Haimova's strategy $\left.{ }^{6}\right)$ used for the preparation

Coralyne chloride (2) of e.g. 2,3,10,11-tetramethoxy-5,6-dihydro- $8 H$-dibenzo[ $[a, g]-$ quinolizin-8-one (3f), because this approach enabled us to react various 1,2,3,4-tetrahydroisoquinoline-1-ones 4 with differently substituted homophthalic acid anhydrides 5 (Scheme 1, see Page 510).

3-Methoxyphenylacetonitrile was hydrogenated with $\mathrm{H}_{2} /$ Raney-Ni. Increased pressure $(60 \mathrm{~atm})$ and elevated temp. $\left(120^{\circ} \mathrm{C}\right)$ are mandatory for quantitative yields of amine 7a. $\beta$-Phenylethylamines 7a-c were cyclized via the pertinent carbamates $8 \mathbf{a}-c^{7}$, obtained from amines $7 \mathbf{a}-\mathbf{c}$ and ethyl chloroformate. Heating the urethanes 8a-c with neat polyphosphoric acid affords the tetrahydroisoquinolin-1ones 4 (Scheme 2).<smiles>[R]c1ccc(CCN)cc1[R4]</smiles>

$$
\begin{aligned}
& \text { a: } R^{1}=-\mathrm{OCH}_{3}, \mathbf{R}^{2}=\mathrm{H} \\
& \mathrm{b}: \mathbf{R}^{1}=-\mathrm{H}, \mathbf{R}^{2}=-\mathrm{OCH}_{3} \\
& \mathrm{c}: \mathbf{R}^{1}=\mathbf{R}^{2}=-\mathrm{OCH}_{3} .
\end{aligned}
$$<smiles>[R]c1ccc(CCNC(=O)OCC)cc1[R]</smiles>

$\mathbf{8}$

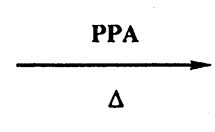

Scheme 2<smiles>[R4]c1cc2c(cc1[R4])C(=O)NCC2</smiles>

4a-s

\footnotetext{
* Dedicated to Prof. Dr. Hartke, Marburg, on the occasion of his 60th birthday.
} 
<smiles>[R]c1cc2c(cc1[R])C(=O)[NH2+]CC2</smiles>

$\underline{4 a} \cdot \mathbf{s}$<smiles>[R]c1cc2c(cc1[R])C(=O)OC(=O)C2</smiles>
5a, b

Isochroman-1,3-diones 5 $\mathrm{a}: \mathbf{R}^{1}=\mathrm{R}^{2}=-\mathrm{OCH}_{3}$ b: $\mathbf{R}^{1}=-\mathrm{H}, \mathbf{R}^{2}=-\mathrm{OCH}_{3}$<smiles>[R4]c1cc2c(cc1[R])-c1cc3cc([R4])c([R4])cc3c(=O)n1CC2</smiles>
1) $\mathrm{BBr}_{3}$ 2) $\mathrm{Ac}_{2} \mathrm{O}$, pyridine

6a- $\mathrm{e}$

same skeleton as 3

\begin{tabular}{|c|c|c|c|c|}
\hline Compound & $\mathrm{R}^{1}$ & $\mathrm{R}^{2}$ & $\mathrm{R}^{3}$ & $\mathrm{R}^{4}$ \\
\hline $3 \mathrm{a}$ & $\mathrm{OCH}_{3}$ & $\mathrm{H}$ & $\mathrm{OCH}_{3}$ & $\mathrm{H}$ \\
$3 \mathrm{~b}$ & $\mathrm{H}$ & $\mathrm{OCH}_{3}$ & $\mathrm{OCH}_{3}$ & $\mathrm{H}$ \\
$3 \mathrm{c}$ & $\mathrm{OCH}_{3}$ & $\mathrm{OCH}_{3}$ & $\mathrm{H}$ & $\mathrm{H}$ \\
$3 \mathrm{~d}$ & $\mathrm{H}$ & $\mathrm{OCH}_{3}$ & $\mathrm{OCH}_{3}$ & $\mathrm{OCH}_{3}$ \\
$3 \mathrm{e}$ & $\mathrm{OCH}_{3}$ & $\mathrm{OCH}_{3}$ & $\mathrm{OCH}_{3}$ & $\mathrm{H}$ \\
$3 \mathrm{f}$ & $\mathrm{OCH}_{3}$ & $\mathrm{OCH}_{3}$ & $\mathrm{OCH}_{3}$ & $\mathrm{OCH}_{3}$ \\
\hline
\end{tabular}

\begin{tabular}{|c|c|c|c|c|}
\hline Compound & $\mathrm{R}^{1}$ & $\mathrm{R}^{2}$ & $\mathrm{R}^{3}$ & $\mathrm{R}^{4}$ \\
\hline $6 \mathrm{a}$ & $\mathrm{OAc}$ & $\mathrm{H}$ & $\mathrm{OAc}$ & $\mathrm{H}$ \\
$6 \mathrm{~b}$ & $\mathrm{H}$ & $\mathrm{OAc}$ & $\mathrm{OAc}$ & $\mathrm{H}$ \\
$6 \mathrm{c}$ & $\mathrm{H}$ & OAc & OAc & OAc \\
$6 \mathrm{~d}$ & $\mathrm{OAc}$ & OAc & OAc & $\mathrm{H}$ \\
$6 \mathrm{e}$ & $\mathrm{OAc}$ & OAc & OAc & OAc \\
\hline
\end{tabular}

Scheme 1

Starting from phenylacetic acid 9, the missing $\mathrm{o}-\mathrm{CH}_{2}-\mathrm{O}$ increment was introduced according to Finkelstein and Brossi ${ }^{8}$. This $o$-hydroxymethylation led to the isochroman 10, which was oxidized to the homophthalic acid 11a. Heat- ing of compounds 11a and b with acetyl chloride led to anhydrides 5 (Scheme 3).

Deviating from this approach 5-methoxyhomophthalic acid (11b) was obtained from bromination of $m$-methoxy-<smiles>COc1ccc(CC(=O)O)cc1OC</smiles><smiles>COc1cc2c(cc1OC)CC(=O)OC2</smiles><smiles></smiles><smiles>[R]c1cc2c(cc1OC)C(=O)OC(=O)C2</smiles><smiles>[2H]c1cc(CC(=O)O)c(C(=O)O)cc1OC</smiles>

5a: $: \mathbf{R}=-\mathrm{OCH}_{3}$ $\underline{5 b}: \mathbf{R}=-\mathbf{H}$ 11a: $: R=-\mathrm{OCH}_{3}$
$\underline{1 \mathbf{b}}: \mathrm{R}=-\mathrm{H}$ 1) $\mathrm{CH}_{3} \mathrm{COCH}_{2} \mathrm{COOEt}$, $\mathrm{NaH} / \mathrm{Cu}_{2} \mathrm{Br}_{2}$ 2) $\mathrm{OH}^{-}$<smiles>COc1cccc(C(=O)O)c1</smiles>

12<smiles>CC(=O)OC(C)(Br)Br</smiles><smiles>COc1ccc(Br)c(C(=O)O)c1</smiles>

13

Scheme 3 
benzoic acid (12) affording 13, and reaction of 13 with ethyl acetoacetate $/ \mathrm{NaH} / \mathrm{Cu}_{2} \mathrm{Br}_{2}$ as described as a general synthesis of homophthalic acids by Bruggink ${ }^{9}$. As outlined in the introduction Haimova's approach ${ }^{6}$ (was used for the synthesis of compounds 3a-f (Scheme 1).

For reasons of comparison we also synthesized the acetoxy derivatives 6a-e. By using $\mathrm{BBr}_{3}$ for the cleavage of the methoxy ethers 3 we found a smooth way for getting the hydroxy derivatives - the temp. used in this procedure is depending on the grade of substitution in the aromatic rings. To avoid oxidative degradation of the free phenols we immediately prepared the acetoxy-8-oxo-5,6-dihydro-dibenzo $[a, g]$ quinolizines 6 by refluxing with acetic acid anhydride/pyridine (Scheme 1).

To get the 9,10-dimethoxy-8-oxo-5,6-dihydro-dibenzo $[a, g]$ quinolizines $\mathbf{3 g}$ and $\mathbf{h}$ (Scheme 4 ) an easy one-step synthesis is the alkaline oxidation of quaternary protoberbinium salts, already described by Gadamer $^{10)}$, starting from berberine- (1) and palmatine chloride (14).

For further comparison of the cytotoxic properties and structure-activity-relationships we also prepared the enamine 15 as a crystalline product ${ }^{11)}$ by reduction of com- pound $3 f$ with $\mathrm{LiAlH}_{4}$ (Scheme 5). Further reduction of 15 with $\mathrm{NaBH}_{4}$ led to racemic xylopinine (16) which was dehydrogenated with iodine to the quaternary 2,3,10,11-tetramethoxyberbinium iodide 17 (Scheme 5).

The NMR-Data of the intermediate 2,3,10,11-tetramethoxyenamine 15 were assigned by NOE-difference-spectra.

Because 5,6-dihydro-8-oxoberbines have a slight angle $\left(18-20^{\circ}\right.$, Fig. 2) in the isoquinoline ring system and the cytotoxic properties often depend on the planarity of a substance, we aromatized the 5,6-dihydro-8-oxoberbine $3 \mathrm{f}$ by dry heating with $\mathrm{Pd} / \mathrm{C}$. According to Dreiding-models and the rules of aromaticity the resulting $8 H$-dibenzo[a,g]quinolizin-8-one 18 (Scheme 4) has a planar ring system with $18 \pi$-electrons.

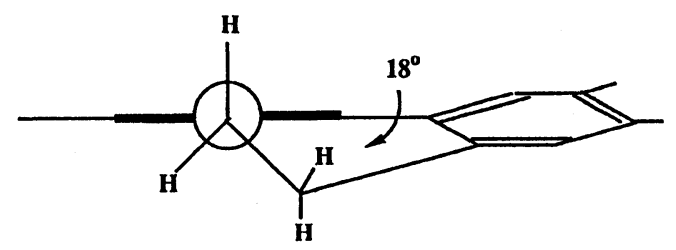

Fig.2: Deviation from planarity (see text).<smiles>[R1]c1cc2c(cc1[R1])-c1cc3ccc(OC)c(OC)c3c(=O)n1CC2</smiles>

$3 \mathrm{~g}: \mathbf{R}^{1}+\mathbf{R}^{2}=-\mathrm{OCH}_{2} \mathrm{O}$ $3 \mathrm{~h}: \mathbf{R}^{\mathbf{1}}=\mathbf{R}^{\mathbf{2}}=-\mathbf{O C H}_{3}$<smiles>COc1cc2cc3c4cc(OC)c(OC)cc4ccn3c(=O)c2cc1OC</smiles><smiles>COc1cc2c(cc1OC)-c1cc3ccncc3c(=O)n1CC2</smiles>

Scheme 4<smiles>COc1cc2c(cc1OC)-c1cc3cc(OC)c(OC)cc3c(=O)n1CC2</smiles><smiles>[CH]C1c2cc(OC)c(OC)cc2C=C2c3cc(OC)c(OC)cc3CCN21</smiles>

$\mathrm{NaBH}_{4}$<smiles></smiles><smiles>COc1cc2c(cc1OC)CN1CCc3cc(OC)c(OC)cc3C1C2</smiles> 


\section{Cytostatic activity}

The MDA-MB-231 cell line ${ }^{12)}$ was used for determination of the cytostatic activity. The cells are hormone-independent mammary tumor cells of human origin. All the 8oxoberbines described were tested for cytostatic effects at a conc. of $10^{-5}$ mole. The inhibition of cell growth was determined by the microtiter essay with spectroscopic measurement of the living cell density ${ }^{13)}$.

Most of our compounds were devoid of activity, with the exception of 3d and 3f, which had equal or better cytostatic properties than berberine (1) and coralyne chloride (2). The tetramethoxy-8-oxoberbine $3 f$ was the most active compound. Replacement of the methoxyphenyl ring (ring D) by a pyridine ring $\left(19^{14)}\right.$, Scheme 4$)$ decreased the cytostatic activity.

Table 1: Cytostatic effect on the growth of MDA-MB 231 cells

\begin{tabular}{|c|c|c|c|}
\hline Compound & $\% \mathrm{~T} / \mathrm{C}^{\mathrm{a}}$ & Compound & $\% \mathrm{~T} / \mathrm{C}^{\mathrm{a}}$ \\
\hline 1 & $41^{b}$ & $6 a$ & $99 \mathrm{~ns}$ \\
\hline 2 & $33^{b}$ & $6 b$ & $76^{b}$ \\
\hline $3 a$ & $95^{\mathrm{ns}}$ & $6 c$ & $77^{b}$ \\
\hline $3 b$ & 99 ns & $6 d$ & $56^{b}$ \\
\hline $3 c$ & $70^{b}$ & $6 e$ & $69 \mathrm{~b}$ \\
\hline $3 d$ & $44^{b}$ & 16 & $75^{b}$ \\
\hline $3 e$ & $98 \mathrm{~ns}$ & 17 & $100^{\mathrm{ns}}$ \\
\hline $3 \mathrm{f}$ & $13^{b}$ & 18 & $100^{\mathrm{ns}}$ \\
\hline $3 g$ & $61^{b}$ & 19 & $89 \mathrm{~b}$ \\
\hline $3 \mathrm{~h}$ & $81^{b}$ & 23 & $97^{\text {ns }}$ \\
\hline $\begin{array}{l}\text { Concen } \\
\text { signific } \\
\text { not sign }\end{array}$ & $\begin{array}{l}\text { ation } 1 \times 10 \\
p<0.01\end{array}$ & M. & \\
\hline
\end{tabular}

\section{Interaction with DNA/RNA}

Interaction of a compound with DNA or RNA often leads to cytostatic effects. In this context intercalation has to be distinguished from unspecific addition to DNA or RNA.

Conventional UV-spectroscopy is frequently used for preliminary studies of interactions with DNA. Berberine (1), e.g., when incubated with native
DNA, shows three isosbestic points in its UV-spectrum, which according to $\mathrm{Krey}^{2)}$ might be indicative for a certain affinity of 1 to DNA. Coralyne (2), however, does not exhibit an isosbestic point under these conditions, but a hypsochromic effect at low concentrations was regarded ${ }^{15)}$ as a hint towards an interaction with DNA; high concentration of 2 leads to a bathochromic shift ${ }^{2}$.

In UV-difference spectroscopy even small deviations from the spectrum taken without DNA can be recognized by shifts of the base line. Sufficient solubility in the DNA-buffer system is a prerequisite for pertinent investigations. We tested our dibenzo[ $a, g]$ quinolizin-8-ones in comparison with ethidium bromide and berberine chloride (1): Most of our protoberberines, especially di- and trimethoxy-derivatives did not show any or only weak interactions with native DNA. Tetramethoxy-substitution, however, causes interference (Fig. 3).

As expected ethidium bromide shows strongest interaction efficacy, followed by compound $3 f$ (line 2). Berberine chloride (1) was nearly ineffective under these conditions. In order to find out whether the interaction of compound $3 \mathrm{f}$ with DNA depends on its concentration, constant aliquots of 3f were added to the DNA-solution: linear increase points towards a concentration-depending interaction with native DNA. After sonication of native DNA ethidium bromide has lost its affinity to DNA whilst the difference spectra with $3 f$ do not differ from each other. Therefore, we suppose that this protoberberinone affects not only the intact DNA but also single DNA-increments. As a consequence we tested interferences of $3 f$ with guanosine, cytidine, adenosine, uridine, and their 5-phosphates as well as with pertinent 2'-desoxy derivatives and thymidine: 3 f shows affinity to 2'-desoxyguanosine, 2'-desoxycytidine and to their phosphates (Fig. 4).

The interaction with 2'-desoxyadenosine is weak, no effect was observed with 2'-desoxyuridine and thymidine. Therefore, we do not expect any specific affinity to native RNA. The cytotoxic trimethoxyprotoberberine 3d does not show any interaction with native DNA or its nucleosides.

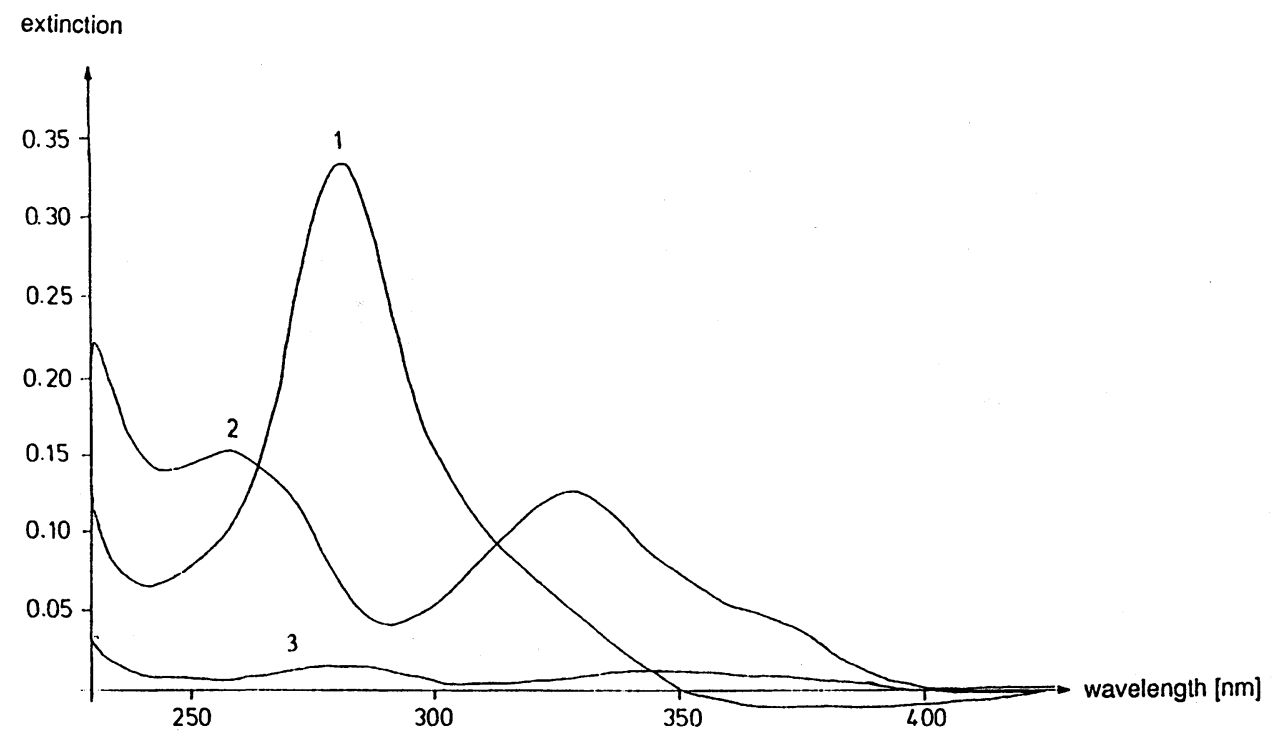

Fig. 3: Difference spectra for $1=$ ethidium bromide, $2=3 f$, and $3=$ berberine chloride; $R=$ [substance]/[DNA] $=1.5$ [mole/mole phosphorus $]$. 


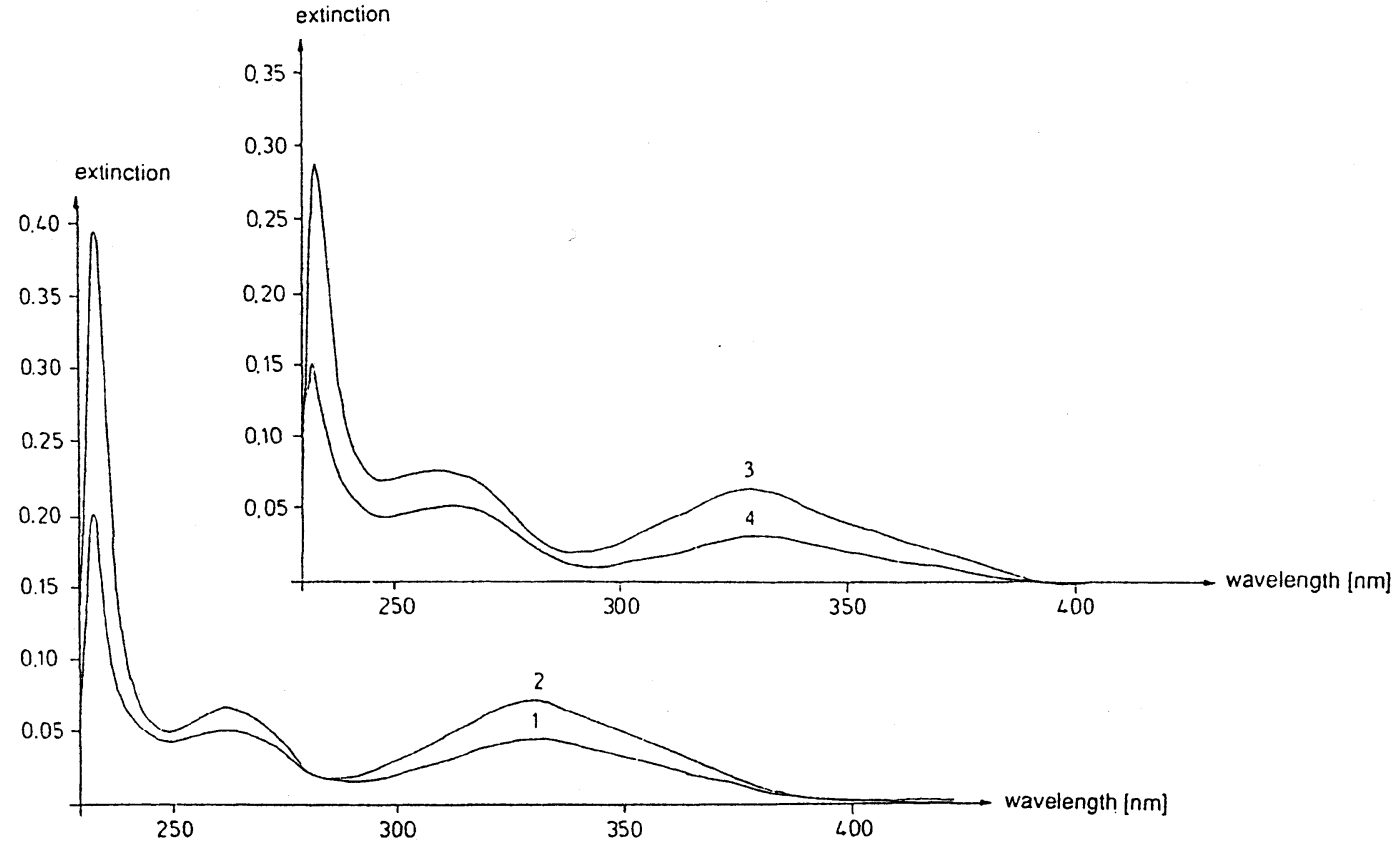

Fig. 4: Difference spectra for $3 f$ with $1=2$ '-desoxyguanosine, $2=2$ '-desoxyguanosine phosphate, $3=2$ '-desoxycytidine and $4=2$ '-desoxycytidine phosphate.

\section{Fluorescence Spectroscopy}

The interaction of $3 f$ with DNA was confirmed by DNAinduced shift of its fluorescence maximum from $425 \mathrm{~nm}$ (3f in DMF plus phosphate buffer saline) to $540 \mathrm{~nm}$ after incubation with DNA for 2 min (cf. Experimental Part).

\section{Displacement of Ethidium bromide}

At high concentrations of salts in the buffer system (ca. 1.0 mole) ethidium bromide interacts with DNA by intercalation, whilst at low ionic strength additional electrostatic binding occurs, caused by reciprocal actions of the phosphate increments with the ethidium cation. These two effects lead to an increase of fluorescence of the ethidium cation which is considered to be a specific test for intercalation ${ }^{16,17}$. Addition of another intercalating substance displaces ethidium bromide and, therefore, diminishes or cancels its fluorescence intensity, depending on the concentration of the displacing compound. The $\mathrm{C}_{50}$-values ( $50 \%$ fluorescence quenching) obtained according to McGhee and von Hippel ${ }^{18)}$ are used to determine binding constants of our substances under consideration.

For our experiments we have used the ratio [DNA $=$ mole phosphorus] $/[$ mole ethidium bromide] $=2.0$ in order to get sufficient fluorescence intensity at the beginning of the titration. Moreover, a low ionic strength was adjusted to leave both opportunities of binding open (vide supra). Experiments were run with those protoberberinones exhibiting significant effects at MDA-MB-231 cells (Table 1) ${ }^{19}$. Actinomycin D was used as a positive control ${ }^{20)}$; this compound displaces ethidium bromide irreversibly. Fig. 5 shows that actinomycin D replaces ethidium bromide, whilst the protoberberinones tested do not.

\section{Viscosity experiments}

Intercalating substances lead to increased length of DNA for about $3.4 \AA$ by partial unwinding ${ }^{21)}$ accompanied by changing of the torsion angle (ethidium bromide, e.g., gives rise to an alteration of a least $12^{\circ 22}$ ). At the same time intercalation stabilizes DNA so increasing its viscosity. Therefore, intercalating properties can be determined by titration of DNA with the intercalating molecule. By this method intercalation of coralyne (2) into native DNA - analogous to that of ethidium bromide - has been detected ${ }^{15)}$.

Titration of native DNA with protoberberinone $3 \mathrm{f}$ indicated that this test compound - contrary to ethidium bromide - does not increase the relative viscosity of DNA, so corroborating the results of the displacement experiment and of the test with sonicated DNA. Obviously $3 f$ (and similar protoberberinones?) does interfere with native DNA, but not by intercalation.

\section{Discussion}

Among the tetramethoxy-8H-dibenzo[a,g]quinolizin-8ones, only $3 f$ shows strong cytostatic activity against MDAMB-231 human mammary tumor cells with a better effect than the original protoberberines berberine (1) or coralyne chloride (2). This effect can be rationalized by an interaction with DNA. However, a direct intercalation into DNA can be ruled out. Based on these findings, we have synthesized C-5-, C-6- and C-13-alkylated derivatives to improve these effects ${ }^{19)}$. In the case of the acetoxy derivatives, this structural modifications should give rise to binding affinity for the estrogen receptor, a prerequisite for a selective action on estrogen receptor positive tumors like mammary carcinomas ${ }^{19}$ ).

The authors thank $M$. Beer and R. Brunner-Ploss for technical assistance and the Deutsche Forschungsgemeinschaft (SFB 234) for financial support. 


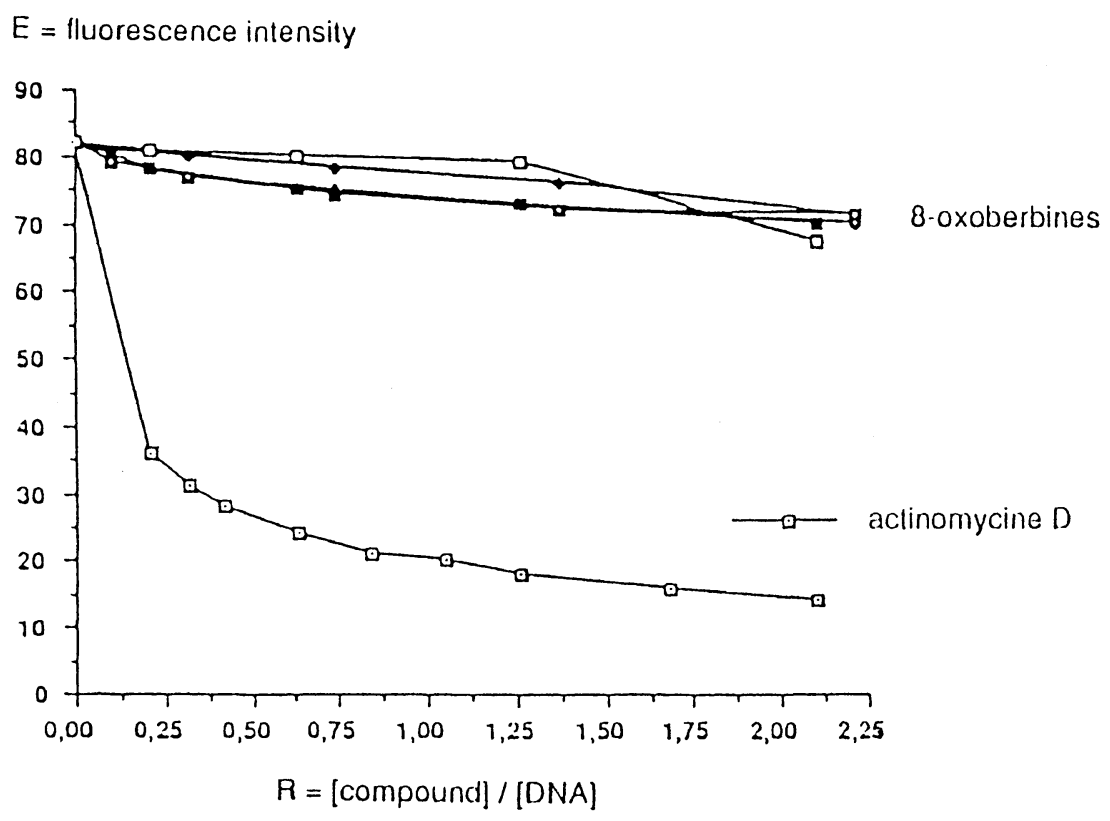

Fig. 5: Fluorescence intensity, plotted against the molar relation [compound]/[DNA].

\section{Experimental Part}

Melting points: Büchi 510 apparatus, uncorrected.- Elemental analyses: Mikroanalytisches Laboratorium, University of Regensburg.- IR-spectra: Beckman Acculab III; KBr.- 'H-NMR-spectra: Varian EM 390 (90 MHz), Bruker WM $250(250 \mathrm{MHz})$; TMS as internal standard.- UV-(difference)spectra: Uvikon 810 (Kontron); solvent: acetonitrile.- Fluorescence-spectra: Hitachi F-3000.- Mass-spectra: Varian MAT CH 5.

\section{Dihydro-dibenzo[a,g]quinolizines 3a-f}

1-Oxoisoquinoline 4 (5 mmole) is suspended in chlorobenzene p.a. (15 $\mathrm{ml})$, pyridine p.a. $(0.41 \mathrm{ml})$ and $\mathrm{POCl}_{3}(0.21 \mathrm{ml}$ in $5 \mathrm{ml}$ chlorobenzene p.a.) are added. The suspension is stirred for $15 \mathrm{~min}$ at room temp., then homophthalic acid anhydride 5 (4.55 mmole) is added slowly. The mixture is stirred again for $15 \mathrm{~min}$, then refluxed for $1 \mathrm{~h}$, cooled again and dissolved in $\mathrm{CH}_{2} \mathrm{Cl}_{2}(50 \mathrm{ml})$. The org. layer is washed with $10 \% \mathrm{NaOH}(3 \times 40 \mathrm{ml})$, dried $\left(\mathrm{Na}_{2} \mathrm{SO}_{4}\right)$ and evaporated. The remaining oil is purified by $\mathrm{CC}\left(\mathrm{SiO}_{2}\right.$; EtOAc) and crystallized from ether. The crystals of 3a-f are colorless and recrystallized from EtOH.- Yields: 55-70\%.

\section{5,6-Dihydro-2,10-dimethoxy-8H-dibenzo[a,g]quinolizin-8-one (3a)}

3a was synthesized from $4 b$ and 5b; m.p. $152^{\circ} \mathrm{C}$.- $\mathrm{C}_{19} \mathrm{H}_{17} \mathrm{NO}_{3}$ (307.4) Calc. C 74.3 H 5.58 N 4.6 Found C 74.0 H 5.55 N 4.4.- IR (KBr): 1645 (-CO) $\mathrm{cm}^{-1}$. ${ }^{1} \mathrm{H}-\mathrm{NMR}\left(\mathrm{CDCl}_{3}\right): \delta(\mathrm{ppm})=2.88\left(\mathrm{t} ; \mathrm{J}=6 \mathrm{~Hz} ; 2 \mathrm{H} ;-\mathrm{CH}_{2}-;\right.$ $\mathrm{H}-5), 3.80$ (s; $\left.3 \mathrm{H} ;-\mathrm{OCH}_{3}\right), 3.87\left(\mathrm{~s} ; 3 \mathrm{H} ;-\mathrm{OCH}_{3}\right), 4.33(\mathrm{t} ; \mathrm{J}=6 \mathrm{~Hz} ; 2 \mathrm{H}$; $-\mathrm{CH}_{2}$; $\left.\mathrm{H}-6\right), 6.73-7.90(\mathrm{~m} ; 6 \mathrm{H}$ arom and $1 \mathrm{H}$ vinyl).- $\mathrm{UV}: \lambda \max (\log \varepsilon)=$ 326 (4.27), 255 (4.12), $221 \mathrm{~nm}(4.26)$.

\section{5,6-Dihydro-3,10-dimethoxy-8H-dibenzo[a,g]quinolizin-8-one (3b)}

From 4a and 5b; m.p. $176-177^{\circ} \mathrm{C}$. $-\mathrm{C}_{19} \mathrm{H}_{17} \mathrm{NO}_{3} \cdot 1 / 2 \mathrm{H}_{2} \mathrm{O}$ (316.4) Calc. $\mathrm{C}$ 72.2 H 5.73 N 4.4 Found C 72.0 H 5.81 N 4.3.- IR (KBr): 1645 (-CO) $\mathrm{cm}^{-1}$.- ${ }^{1} \mathrm{H}-\mathrm{NMR}\left(\mathrm{CDCl}_{3}\right): \delta(\mathrm{ppm})=2.87\left(\mathrm{t} ; \mathrm{J}=6 \mathrm{~Hz} ; 2 \mathrm{H} ;-\mathrm{CH}_{2}-\mathrm{H}-5\right)$, 3.77 (s; $\left.3 \mathrm{H} ;-\mathrm{OCH}_{3}\right), 3.87\left(\mathrm{~s} ; 3 \mathrm{H} ;-\mathrm{OCH}_{3}\right), 4.33\left(\mathrm{t} ; \mathrm{J}=6 \mathrm{~Hz} ; 2 \mathrm{H} ;-\mathrm{CH}_{2}-\right.$; $\mathrm{H}-6), 6.57-7.92(\mathrm{~m} ; 6 \mathrm{H}$ arom and $1 \mathrm{H}$ vinyl).- UV: $\lambda \max (\log \varepsilon)=327$ (4.38), 255 (4.17), $214 \mathrm{~nm}(4.44)$.- MS: $\mathrm{m} / \mathrm{z}=307\left(100 \%, \mathrm{M}^{+}\right), 292\left(80{ }^{*}\right.$ $\left.277.73\left(\mathrm{M}-\mathrm{CH}_{3}\right)^{+}\right), 277(4), 153.5\left(10, \mathrm{M}^{2+}\right)$.

\section{5,6-Dihydro-2,3-dimethoxy-8H-dibenzo[a,g]quinolizin-8-one (3c)}

From $4 \mathrm{c}$ and homophthalic acid anhydride (Fa. Aldrich); m.p. $175^{\circ} \mathrm{C}$, lit. $181-182^{\circ} \mathrm{C}^{23)}$.

5,6-Dihydro-3,10,11-trimethoxy-8H-dibenzo[a,g]quinolizin-8-one (3d)

From 4a and 5a; m.p. $185-186^{\circ} \mathrm{C}$.- $\mathrm{C}_{20} \mathrm{H}_{19} \mathrm{NO}_{4} \times 1 / 2 \mathrm{EtOH}(360.4)$ Calc. C 70.0 H 6.15 N 3.9 Found C 70.3 H 5.82 N 4.1.- IR (KBr): 1650 (-CO) $\mathrm{cm}^{-1}$.- ${ }^{1} \mathrm{H}-\mathrm{NMR}\left(\mathrm{CDCl}_{3}\right): \delta(\mathrm{ppm})=2.93\left(\mathrm{t} ; \mathrm{J}=6 \mathrm{~Hz} ; 2 \mathrm{H} ;-\mathrm{CH}_{2}-\mathrm{H}-5\right)$, $3.82\left(\mathrm{~s} ; 3 \mathrm{H} ;-\mathrm{OCH}_{3}\right), 3.97\left(\mathrm{~s} ; 6 \mathrm{H} ;-\mathrm{OCH}_{3}\right), 4.35\left(\mathrm{t} ; \mathrm{J}=6 \mathrm{~Hz} ; 2 \mathrm{H} ;-\mathrm{CH}_{2}-;\right.$ $\mathrm{H}-6), 6.70-7.03(\mathrm{~m} ; 3 \mathrm{H}$ arom and $1 \mathrm{H}$ vinyl), 7.60-7.90 (m; $2 \mathrm{H}$ arom).- UV: $\lambda \max (\log \varepsilon)=328$ (4.27), 252 (4.31), $218 \mathrm{~nm}(4.29)$.

\section{5,6-Dihydro-2,3,10-trimethoxy-8H-dibenzo[a,g]quinolizin-8-one (3e)}

From $4 \mathrm{c}$ and 5b; m.p. $157-158^{\circ} \mathrm{C}$.- $\mathrm{C}_{20} \mathrm{H}_{19} \mathrm{NO}_{4}$ (337.4) Calc. C $71.2 \mathrm{H}$ $5.68 \mathrm{~N} 4.2$ Found C $70.8 \mathrm{H} 5.60 \mathrm{~N}$ 4.0.- IR (KBr): $1645(-\mathrm{CO}) \mathrm{cm}^{-1}$.${ }^{1} \mathrm{H}-\mathrm{NMR}\left(\mathrm{CDCl}_{3}\right): \delta(\mathrm{ppm})=2.87\left(\mathrm{t} ; \mathrm{J}=6 \mathrm{~Hz} ; 2 \mathrm{H} ;-\mathrm{CH}_{2}-\mathrm{H}-5\right), 3.85$ (s; $\left.6 \mathrm{H} ;-\mathrm{OCH}_{3}\right), 3.93\left(\mathrm{~s} ; 3 \mathrm{H} ;-\mathrm{OCH}_{3}\right), 4.32\left(\mathrm{t} ; \mathrm{J}=6 \mathrm{~Hz} ; 2 \mathrm{H} ;-\mathrm{CH}_{2}-\mathrm{H}-6\right), 6.65$, $6.77(\mathrm{~s} ; 1 \mathrm{H}$ arom and $1 \mathrm{H}$ vinyl), 7.07-7.53 (m; $3 \mathrm{H}$ arom), $7.77(\mathrm{~d} ; \mathrm{J}=2 \mathrm{~Hz}$; $1 \mathrm{H}$ arom; H-9).- UV: $\lambda \max (\log \varepsilon)=322(4.31), 256(4.04), 217 \mathrm{~nm}$ (4.25).

\section{5,6-Dihydro-2,3,10,11-tetramethoxy-8H-dibenzo[a,g]quinolizin-8-one (3i)}

From $4 \mathrm{c}$ and $5 \mathrm{a}$; m.p. $194^{\circ} \mathrm{C}$, lit. $190^{\circ} \mathrm{C}^{24)}$ - MS: $\mathrm{m} / \mathrm{z}=367\left(100 \%, \mathrm{M}^{+}\right)$, $352\left(54,{ }^{*} 337.61\left(\mathrm{M}-\mathrm{CH}_{3}\right)^{+}\right), 183.5\left(23, \mathrm{M}^{2+}\right)$.

\section{Lactams 4a-c}

Polyphosphoric acid $(100 \mathrm{~g})$ is preheated to $140^{\circ} \mathrm{C}$ (oil bath temp.). After reaching this temp. carbamate $8(50 \mathrm{mmole})$ is directly poured onto the polyphosphoric acid and refluxed for $1 \mathrm{~h}$. After cooling the mixture is suspended in ice water $(100 \mathrm{ml})$. While cooling the solution is alkalized with $\mathrm{NaOH}(40 \%)$ and extracted with $\mathrm{CH}_{2} \mathrm{Cl}_{2}(6 \times 150 \mathrm{ml})$. The combined org. layers are dried $\left(\mathrm{Na}_{2} \mathrm{SO}_{4}\right)$ and evaporated. The remaining oil is purified by $\mathrm{CC}\left(\mathrm{SiO}_{2} ; \mathrm{EtOAc}\right)$ and crystallized from ether. The crystals of $4 \mathrm{a}-\mathrm{c}$ are colorless and recrystallized from ether.- Yields: 50-60\%. 


\section{1,2,3,4-Tetrahydro-6-methoxy-1-oxo-isoquinoline (4a)}

Prepared from 8a; m.p. $139^{\circ} \mathrm{C}$, lit. $139^{\circ} \mathrm{C}^{25)}$. UV: $\lambda \max (\log \varepsilon)=285$ (3.35), $250 \mathrm{~nm}$ (4.09).

\section{1,2,3,4-Tetrahydro-7-methoxy-1-oxo-isoquinoline (4b)}

From 8b; m.p. $86^{\circ} \mathrm{C}$, lit. $\left.86-88^{\circ} \mathrm{C}^{26}\right)$. UV: $\lambda \max (\log \varepsilon)=299$ (3.37), $229 \mathrm{~nm}$ (3.96).

\section{1,2,3,4-Tetrahydro-6,7-dimethoxy-1-oxo-isoquinoline (4c)}

From 8c; m.p. $174^{\circ} \mathrm{C}$, lit. $173.5-174.5^{\circ} \mathrm{C}^{27)}$. UV: $\lambda \max (\log \varepsilon)=293$ (3.76), $255 \mathrm{~nm}$ (3.94).

\section{Carbamates 8a-c}

100 mmole of the corresponding $\beta$-phenylethylamine 7 are dissolved with $\mathrm{NEt}_{3}(10.0 \mathrm{~g})$ in absol. $\mathrm{CH}_{2} \mathrm{Cl}_{2}(50 \mathrm{ml})$. After addition of ethyl chloroformate $(10.8 \mathrm{~g})$ in $50 \mathrm{ml}$ absol. $\mathrm{CH}_{2} \mathrm{Cl}_{2}$ the mixture is stirred for $1 \mathrm{~h}$. The precipitate is dissolved with $2 \mathrm{~N} \mathrm{HCl}$ and stirred again. After washing with $\mathrm{H}_{2} \mathrm{O}$ the org. layer is dried $\left(\mathrm{Na}_{2} \mathrm{SO}_{4}\right)$ and evaporated. The remaining oils or precipitates are used without further purification.- Yields: nearly quantitative.

\section{Ethyl-N-[2-(3-methoxyphenyl)ethyl]-carbamate (8a)}

Prepared from 7a and ethyl chloroformate (Fa. Aldrich); $\mathrm{C}_{12} \mathrm{H}_{17} \mathrm{NO}_{3}$ (223.3).- IR (film): 3340 (-NH-), 1710 (-CO) $\mathrm{cm}^{-1}$.- ${ }^{1} \mathrm{H}-\mathrm{NMR}\left(\mathrm{CDCl}_{3}\right): \delta$ $(\mathrm{ppm})=1.25\left(\mathrm{t} ; \mathrm{J}=7.5 \mathrm{~Hz} ; 3 \mathrm{H} ;-\mathrm{CH}_{3}\right), 2.80\left(\mathrm{t} ; \mathrm{J}=7.5 \mathrm{~Hz} ; 2 \mathrm{H} ;-\mathrm{CH}_{2}-\mathrm{CH}_{2}-\right.$ $\mathrm{NH}-$ ), 3.40 ("q"; J = $7.5 \mathrm{~Hz} ; 2 \mathrm{H} ;-\mathrm{CH}_{2}-\mathrm{CH}_{2}-\mathrm{NH}-$ ), 3.77 (s; $3 \mathrm{H} ;-\mathrm{OCH}_{3}$ ), 4.10 (q; J = 7.5 Hz; $2 \mathrm{H} ;-\mathrm{CH}_{2}-\mathrm{CH}_{3}$ ), 4.90 (s broad; $1 \mathrm{H}$; - $\mathrm{NH}-$; not exchangeable), 6.67-7.40 ( $\mathrm{m} ; 4 \mathrm{H}$ arom).

\section{Ethyl-N-[2-(4-methoxyphenyl)ethyl]-carbamate (8b)}

From $\beta$-(p-methoxyphenyl)ethylamine and ethyl chloroformate; colorless crystals, m.p. $45^{\circ} \mathrm{C}$ (ether).- $\mathrm{C}_{12} \mathrm{H}_{17} \mathrm{NO}_{3}$ (223.3) Calc. C $64.6 \mathrm{H} 7.67 \mathrm{~N} 6.3$ Found C $64.4 \mathrm{H} 7.64 \mathrm{~N}$ 6.2.- IR (KBr): 3340 (-NH-), 1710 (-CO) $\mathrm{cm}^{-1}$.${ }^{1} \mathrm{H}-\mathrm{NMR}\left(\mathrm{CDCl}_{3}\right): \delta(\mathrm{ppm})=1.20\left(\mathrm{t} ; \mathrm{J}=7.5 \mathrm{~Hz} ; 3 \mathrm{H} ;-\mathrm{CH}_{2}-\mathrm{CH}_{3}\right), 2.70$ (t; J = 7.5 Hz; 2H; - $\mathrm{CH}_{2}-\mathrm{CH}_{2}-\mathrm{NH}-$ ), 3.40 ("q"; J = 7.5 Hz; $2 \mathrm{H} ;-\mathrm{CH}_{2}-\mathrm{CH}_{2}-$ $\mathrm{NH}-$ ), 3.77 (s; $\left.3 \mathrm{H} ;-\mathrm{OCH}_{3}\right), 4.10\left(\mathrm{q} ; \mathrm{J}=7.5 \mathrm{~Hz} ; 2 \mathrm{H} ;-\mathrm{CH}_{2}-\mathrm{CH}_{3}\right), 4.67$ (s broad; 1H; -NH-; not exchangeable), 6.70-7.33 (m; 4H arom).

\section{Ethyl-N-[2-(3,4-dimethoxyphenyl)ethyl]-carbamate (8c)}

From homoveratrylamine (Fa. Fluka) and ethyl chloroformate; white solid, m.p. $61-62^{\circ} \mathrm{C}$ (ether), lit. $64-66^{\circ} \mathrm{C}^{28}$ ).

\section{1-Amino-2-(3-methoxyphenyl)ethane (7a)}

200 mmole 3-methoxyphenylacetonitrile (Fa. Fluka), dissolved in EtOH $\left(150 \mathrm{ml}\right.$, saturated with $\left.\mathrm{NH}_{3}\right)$ are hydrogenated in the presence of Raney-Ni (from $1.5 \mathrm{~g}$ alloy) at $60 \mathrm{~atm}$ and $120^{\circ} \mathrm{C}$ for about $4 \mathrm{~h}$. The catalyst is filtered off, washed with $\mathrm{EtOH}$ and the solvent is evaporated: pure, colorless oil, b.p. $87^{\circ} \mathrm{C}, 0.2 \mathrm{~T}$; lit. $122-123^{\circ} \mathrm{C}, 7 \mathrm{~mm}^{29)}$. - Yield: $90-95 \%$.

\section{Isochroman-1,3-diones 5a and b}

A suspension of homophthalic acid 11 (15 mmole) and acetylchloride $(30 \mathrm{ml})$ are refluxed under stirring for $1 \mathrm{~h}$, then the excess of reagent is distilled off. $25 \mathrm{ml}$ of absol. ether are added to the residue, the crystallized product is washed with ether and dried.- Yields: $60-65 \%$.

\section{6,7-Dimethoxy-isochroman-1,3-dione (5a)}

Prepared from 11a; colorless crystals, m.p. $174-176^{\circ} \mathrm{C}$ (ether), lit. $175^{\circ} \mathrm{C}^{30)}$.

\section{7-Methoxy-isochroman-1,3-dione (5b)}

From 11b; light-brown crystals, m.p. $131-134^{\circ} \mathrm{C}$ (ether), lit. 142$143^{\circ} \mathrm{C}^{31)}$.

\section{6,7-Dimethoxyisochroman-3-one (10)}

3,4-Dimethoxyphenylacetic acid (9) (200 mmole; Fa. Merck) is heated with glacial acetic acid $(200 \mathrm{ml})$ on the steam bath. Formaline solution $(37 \%, 40 \mathrm{ml})$ and conc. $\mathrm{HCl}(40 \mathrm{ml})$ are added and the mixture is stirred on the steam bath under reflux for $1 \mathrm{~h} . \mathrm{H}_{2} \mathrm{O}(200 \mathrm{ml})$ is added, the solution is extracted with $\mathrm{CHCl}_{3}(3 \times 200 \mathrm{ml})$. The combined org. layers are washed with $10 \% \mathrm{NaHCO}_{3}$-solution, dried $\left(\mathrm{Na}_{2} \mathrm{SO}_{4}\right)$ and evaporated. The residue is crystallized by adding some drops of $\mathrm{EtOH}$ or ether.- Yield: $90 \%$. Colorless crystals, m.p. $98-99^{\circ} \mathrm{C}$ (EtOH), lit. $102-103^{\circ} \mathrm{C}^{32}$.

\section{4,5-Dimethoxyhomophthalic acid (11a)}

$100 \mathrm{mmole}$ lactone 10 are dissolved in $10 \% \mathrm{KOH} / \mathrm{H}_{2} \mathrm{O}(110 \mathrm{ml})$. Under stirring $2 \% \mathrm{KMnO}_{4}$-solution $(1600 \mathrm{ml})$ is added quickly, the solution is stirred at room temp. for $10 \mathrm{~h}$. EtOH $(20 \mathrm{ml})$ is added and the mixture is heated on the steam bath. After filtration the water layer is concentrated and acidified with conc. $\mathrm{HCl}$. The precipitate is recrystallized from $\mathrm{H}_{2} \mathrm{O}$.Yield: $90-95 \%$.- Colorless crystals, m.p. $206-208^{\circ} \mathrm{C}\left(\mathrm{H}_{2} \mathrm{O}\right)$, lit. 213 $214^{\circ} \mathrm{C}^{32)}$.

\section{2-Bromo-5-methoxybenzoic acid (13)}

0.24 mole of m-anisic acid (Fa. Aldrich) are dissolved in $\mathrm{NaOH} / \mathrm{H}_{2} \mathrm{O}$ ( $10.7 \mathrm{~g} / 267.5 \mathrm{mmole} \mathrm{NaOH}$ in $400 \mathrm{ml} \mathrm{H}_{2} \mathrm{O}$ ). After heating to $50-60^{\circ} \mathrm{C} 12.9$ $\mathrm{ml}(0.25$ mole $)$ of $\mathrm{Br}_{2}$ are added slowly, then the solution is stirred for 30 min. While cooling $\mathrm{NaHSO}_{3}$-solution is added until the mixture is colorless. The precipitate is dried.- Yield: $70-80 \%$.- Colorless crystals, m.p. $157-158^{\circ} \mathrm{C}$ (EtOH $\left.96 \%\right)$, lit. $162^{\circ} \mathrm{C}^{31}$.

\section{5-Methoxyhomophthalic acid (11b)}

$11 \mathrm{~b}$ is prepared from 13 according to Bruggink ${ }^{9)}$.- Yield: 60-70\%: lightbrown crystals, m.p. $184-186^{\circ} \mathrm{C}\left(\mathrm{CH}_{2} \mathrm{Cl}_{2} / \mathrm{MeOH} / \mathrm{H}_{2} \mathrm{O}\right)$, lit. $\left.184-186^{\circ} \mathrm{C}^{9}\right)$.

\section{Acetoxy-dihydro-dibenzo[a,g]quinolizines6a-e}

a) Ether cleavage

$100 \mathrm{mg}$ methoxyoxoberbine 3 (in $10 \mathrm{ml}$ of absol. $\mathrm{CH}_{2} \mathrm{Cl}_{2}$ ) are added dropwise to $0.1 \mathrm{ml}$ of $\mathrm{BBr}_{3}$ in $10 \mathrm{ml}$ of absol. $\mathrm{CH}_{2} \mathrm{Cl}_{2}$, then refluxed for $1 \mathrm{~h}$ and stirred at room temp. for $12 \mathrm{~h}$. While cooling saturated $\mathrm{NaHCO}_{3}$-solution (10-15 ml) is added and the suspension is mixed with EtOAc to get a clear solution. The org. layer is separated, the water layer is extracted again with EtOAc $(2 \times 50 \mathrm{ml})$. The combined org. layer are washed with saturated $\mathrm{NaCl}$-solution, dried $\left(\mathrm{Na}_{2} \mathrm{SO}_{4}\right)$ and evaporated. Generally the residue is dried for a short time i. vac., then it is acetylated immediately.

\section{b) Acetylation}

The residue from a) is refluxed with $\mathrm{Ac}_{2} \mathrm{O}(6 \mathrm{ml})$ and absol. pyridine (5 drops) for $2 \mathrm{~h}$, then the excess of reagents is evaporated $i$. vac. After cooling the remaining oil is crystallized from $\mathrm{MeOH}$ and the precipitate is washed with ether and dried. Purification: $\mathrm{CC}\left(\mathrm{SiO}_{2}\right.$, EtOAc).- Yields: $70-80 \%$ colorless crystals.

\section{2,10-Diacetoxy-5,6-dihydro-8H-dibenzo[a,g]quinolizin-8-one (6a)}

Prepared from 3a; m.p. $168-169^{\circ} \mathrm{C}(\mathrm{MeOH}) .-\mathrm{C}_{21} \mathrm{H}_{17} \mathrm{NO}_{5} \cdot 1 / 2 \mathrm{CH}_{3} \mathrm{OH}$ (379.4) Calc. C 68.1 H 5.05 N 3.7 Found C 68.4 H 4.90 N 3.8.- IR (KBr): $1750\left(\mathrm{CH}_{3}-\mathrm{CO}\right), 1660(-\mathrm{CO}) \mathrm{cm}^{-1}$.- ${ }^{1} \mathrm{H}-\mathrm{NMR}\left(\mathrm{CDCl}_{3}\right): \delta(\mathrm{ppm})=2.30(\mathrm{~s}$; $\left.6 \mathrm{H} ; \mathrm{H}_{3} \mathrm{C}-\mathrm{CO}-\right), 2.97$ (t; J = $6 \mathrm{~Hz} ; 2 \mathrm{H}$; $\left.-\mathrm{CH}_{2}-\mathrm{H}-5\right), 4.35$ (t; J = $6 \mathrm{~Hz} ; 2 \mathrm{H}$; $-\mathrm{CH}_{2}-$; H-6), 6.87-7.63 (m; $5 \mathrm{H}$ arom and $1 \mathrm{H}$ vinyl), 8.10 (d; J = $2 \mathrm{~Hz} ; 1 \mathrm{H}$ arom; H-9).- UV: $\lambda \max (\log \varepsilon)=329(4.28), 212 \mathrm{~nm}(4.40)$. 


\section{3,10-Diacetoxy-5,6-dihydro-8H-dibenzo[a,g]quinolizin-8-one (6b)}

From 3b; m.p. 206-208 ${ }^{\circ} \mathrm{C}(\mathrm{MeOH})$.- $\mathrm{C}_{21} \mathrm{H}_{17} \mathrm{NO}_{5}$ (363.4) Calc. $\mathrm{C} 69.4 \mathrm{H}$ 4.72 N 3.9 Found C $69.1 \mathrm{H} 4.83 \mathrm{~N}$ 3.9.- IR ( $\mathrm{KBr})$ : $1750\left(\mathrm{CH}_{3}-\mathrm{CO}\right), 1640$ $(-\mathrm{CO}) \mathrm{cm}^{-1} .-{ }^{1} \mathrm{H}-\mathrm{NMR}\left(\mathrm{CDCl}_{3}\right): \delta(\mathrm{ppm})=2.33\left(\mathrm{~s} ; 6 \mathrm{H} ; \mathrm{H}_{3} \mathrm{C}-\mathrm{CO}-\right), 3.00(\mathrm{t}$; $\left.\mathrm{J}=6 \mathrm{~Hz} ; 2 \mathrm{H} ;-\mathrm{CH}_{2}-\mathrm{H}-5\right), 4.42\left(\mathrm{t} ; \mathrm{J}=6 \mathrm{~Hz} ; 2 \mathrm{H} ;-\mathrm{CH}_{2}-\mathrm{H}-6\right), 6.90-8.20$ $(\mathrm{m} ; 6 \mathrm{H}$ arom and $1 \mathrm{H}$ vinyl).- $\mathrm{UV}: \lambda \max (\log \mathrm{e})=331$ (4.34), $209 \mathrm{~nm}(4.79)$.

\section{3,10,11-Triacetoxy-5,6-dihydro-8H-dibenzo[a,g]quinolizin-8-one (6c)}

From 3d; m.p. $217-219^{\circ} \mathrm{C}(\mathrm{MeOH}) .-\mathrm{C}_{23} \mathrm{H}_{19} \mathrm{NO}_{7} \cdot 1 / 2 \mathrm{CH}_{3} \mathrm{OH}(437.4)$ Calc. C 64.5 H 4.84 N 3.2 Found C 64.7 H 4.73 N 3.0.- IR (KBr): 1775 $\left(\mathrm{CH}_{3}-\mathrm{CO}\right), 1645(-\mathrm{CO}) \mathrm{cm}^{-1}$.- ${ }^{1} \mathrm{H}-\mathrm{NMR}\left(\mathrm{CDCl}_{3}\right): \delta(\mathrm{ppm})=2.32(\mathrm{~s} ; 9 \mathrm{H}$; $\left.\mathrm{H}_{3} \mathrm{C}-\mathrm{CO}-\right), 2.93\left(\mathrm{t} ; \mathrm{J}=6 \mathrm{~Hz} ; 2 \mathrm{H} ;-\mathrm{CH}_{2} ; \mathrm{H}-5\right), 4.32\left(\mathrm{t} ; \mathrm{J}=6 \mathrm{~Hz} ; 2 \mathrm{H} ;-\mathrm{CH}_{2}-\right.$; $\mathrm{H}-6), 6.92(\mathrm{~d} ; \mathrm{J}=2 \mathrm{~Hz} ; 1 \mathrm{H}$ arom; $\mathrm{H}-4), 7.00-7.12(\mathrm{~m} ; 1 \mathrm{H}$ arom and $1 \mathrm{H}$ vinyl), 7.42 (s; $1 \mathrm{H}$ arom), 7.78 (dd; $\mathrm{J}_{1 / 2}=9 / 2 \mathrm{~Hz} ; 1 \mathrm{H}$ arom; $\mathrm{H}-2$ ), 8.22 (s; $1 \mathrm{H}$ arom).- UV: $\lambda \max (\log \varepsilon)=326$ (4.32), $216 \mathrm{~nm}$ (4.33).

\section{2,3,10-Triacetoxy-5,6-dihydro-8H-dibenzo[a,g]quinolizin-8-one (6d)}

From 3e; m.p. $202-205^{\circ} \mathrm{C}(\mathrm{MeOH}) .-\mathrm{C}_{23} \mathrm{H}_{19} \mathrm{NO}_{7} \cdot 1 / 2 \mathrm{H}_{2} \mathrm{O}$ (430.4) Calc. C $64.1 \mathrm{H} 4.68 \mathrm{~N} 3.3$ Found C 63.8 H 4.66 N 3.0.- IR (KBr): 1765; 1775 $\left(\mathrm{CH}_{3}-\mathrm{CO}\right), 1660(-\mathrm{CO}) \mathrm{cm}^{-1}$.- ${ }^{1} \mathrm{H}-\mathrm{NMR}\left(\mathrm{CDCl}_{3}\right): \delta(\mathrm{ppm})=2.17(\mathrm{~s} ; 3 \mathrm{H}$; $\left.\mathrm{H}_{3} \mathrm{C}-\mathrm{CO}-\right), 2.30$ (s; 6H; $\left.\mathrm{H}_{3} \mathrm{C}-\mathrm{CO}-\right), 2.97\left(\mathrm{t} ; \mathrm{J}=6 \mathrm{~Hz} ; 2 \mathrm{H} ;-\mathrm{CH}_{2}-\mathrm{H}-5\right), 4.35$ (t; J = $6 \mathrm{~Hz} ; 2 \mathrm{H}$; - $\mathrm{CH}_{2}-\mathrm{H}-6$ ), 6.93 (s broad; $1 \mathrm{H}$ vinyl; $\mathrm{H}-13$ ), 7.13 (s broad; $1 \mathrm{H}$ arom), 7.43 ("d"; J = 2 Hz; 1H arom), 7.53 (s; 1H arom), 7.63 (s; $1 \mathrm{H}$ arom), 8.08 (d; J = $2 \mathrm{~Hz} ; 1 \mathrm{H}$ arom; H-9).- UV: $\lambda \max (\log \varepsilon)=330$ (4.30), $215 \mathrm{~nm}(4.37)$.

\section{2,3,10,11-Tetraacetoxy-5,6-dihydro-8H-dibenzo[a,g]quinolizin-8-one(6e)}

From 3f; m.p. $244-245^{\circ} \mathrm{C}(\mathrm{MeOH})$ - $\mathrm{C}_{25} \mathrm{H}_{21} \mathrm{NO}_{9}$ (479.4) Calc. C $62.6 \mathrm{H}$ $4.41 \mathrm{~N} 2.9$ Found $\mathrm{C} 62.2 \mathrm{H} 4.04 \mathrm{~N}$ 2.8.- IR (KBr): $1775\left(\mathrm{CH}_{3}-\mathrm{CO}\right), 1655$ $(-\mathrm{CO}) \mathrm{cm}^{-1} .{ }^{1} \mathrm{H}-\mathrm{NMR}\left(\mathrm{CDCl}_{3}\right): \delta(\mathrm{ppm})=2.30\left(\mathrm{~s} ; 12 \mathrm{H} ; \mathrm{H}_{3} \mathrm{C}-\mathrm{CO}-\right), 2.96$ $\left(\mathrm{t} ; \mathrm{J}=6 \mathrm{~Hz} ; 2 \mathrm{H},-\mathrm{CH}_{2}-\mathrm{H}-5\right), 4.33\left(\mathrm{t} ; \mathrm{J}=6 \mathrm{~Hz} ; 2 \mathrm{H} ;-\mathrm{CH}_{2} ; \mathrm{H}-6\right), 6.87$, $7.12,7.41,7.61,8.20(\mathrm{~s} ; 4 \mathrm{H}$ arom and $1 \mathrm{H}$ vinyl).- $\mathrm{UV}: \lambda \max (\log \varepsilon)=329$ (4.34), $216 \mathrm{~nm}(4.37)$.

\section{Dihydro-dibenzo[a,g]quinolizines $\mathbf{3 g}$ and $\mathbf{h}$}

To 50 mmole berberin- (1) or palmatine chloride (14), dissolved in hot $\mathrm{H}_{2} \mathrm{O}(500 \mathrm{ml})$, are dropped $150 \mathrm{~g} \mathrm{KOH}$ in $70 \mathrm{ml} \mathrm{H}_{2} \mathrm{O}$. The mixture is stirred for $15 \mathrm{~min}$ and extracted with ether $(3 \times 500 \mathrm{ml})$. The black-brown precipitate is stirred with hot ether for $15 \mathrm{~min}$ and filtrated. The combined ether layers are washed with water, dried $\left(\mathrm{Na}_{2} \mathrm{SO}_{4}\right)$ and evaporated. Purification: $\mathrm{CC}\left(\mathrm{SiO}_{2}, \mathrm{EtOAc}\right)$.- Yields: $40-50 \%$.

5,6-Dihydro-9,10-dimethoxy-2,3-methylendioxy-8H-dibenzo[a,g]quinolizin-8-one $(3 \mathrm{~g})$

From berberine chloride (Fa. Sigma); white-yellow crystals, m.p. 188$190^{\circ} \mathrm{C}(\mathrm{EtOH})$, lit. $199.5^{\circ} \mathrm{C}^{33)}$.

\section{5,6-Dihydro-2,3,9,10-tetramethoxy-8H-dibenzo[a,g]quinolizin-8-one (3h)}

From palmatine chloride (Fa. Sigma); yellow foam, m.p. $183-184^{\circ} \mathrm{C}$ (EtOH, lit. $\left.183^{\circ} \mathrm{C}^{34}\right)$. $-\mathrm{C}_{21} \mathrm{H}_{21} \mathrm{NO}_{5} \cdot 1 / 2 \mathrm{EtOH}(390.4)$ Calc. C $67.7 \mathrm{H} 6.15$ N 3.6 Found C 67.7 H 5.87 N 3.5.- IR (KBr): 1655 (-CO) $\mathrm{cm}^{-1}$.- ${ }^{1} \mathrm{H}-\mathrm{NMR}$ $\left(250 \mathrm{MHz}, \mathrm{CDCl}_{3}\right): \delta(\mathrm{ppm})=2.90\left(\mathrm{t} ; \mathrm{J}=6 \mathrm{~Hz} ; 2 \mathrm{H} ;-\mathrm{CH}_{2} ; \mathrm{H}-5\right), 3.88$, $3.93,3.97,4.00\left(\mathrm{~s} ; 12 \mathrm{H} ;-\mathrm{OCH}_{3}\right), 4.33\left(\mathrm{t} ; \mathrm{J}=6 \mathrm{~Hz} ; 2 \mathrm{H} ;-\mathrm{CH}_{2}-\mathrm{H}-6\right), 6.73$, $6.78(\mathrm{~s} ; 2 \mathrm{H}$ arom), $7.23-7.32(\mathrm{~m} ; 2 \mathrm{H}$ arom and $1 \mathrm{H}$ vinyl).- $\mathrm{UV}$ : $\lambda \max (\log$ $\varepsilon)=327(4.26), 217 \mathrm{~nm}(4.26)$.

\section{5,6-Dihydro-2,3,10,11-tetramethoxy-8H-dibenzo[a,g]quinolizine(15)}

The enamine $\mathbf{1 5}$ is prepared from the 8-oxoberbine $3 \mathrm{f}$ according to Kiparissides ${ }^{11)}$. Yield: $85-90 \%$; yellow precipitate, $\mathrm{C}_{21} \mathrm{H}_{23} \mathrm{NO}_{4}$ (353.4), m.p. $192-195^{\circ} \mathrm{C}$ (dec.), lit. $173-176^{\circ} \mathrm{C}^{11)}$.- NOE-difference-spectra $(250 \mathrm{MHz})$ : a) Enamine: $2.90\left(\mathrm{t} ; \mathrm{J}=6 \mathrm{~Hz} ; 2 \mathrm{H} ;-\mathrm{CH}_{2}-\mathrm{H}-5\right), 3.13(\mathrm{t} ; \mathrm{J}=6 \mathrm{~Hz} ; 2 \mathrm{H}$; $-\mathrm{CH}_{2}-$; H-6), 3.87, 3.88, 3.89 (s; $\left.9 \mathrm{H} ;-\mathrm{OCH}_{3}\right), 3.94\left(\mathrm{~s} ; 3 \mathrm{H} ;-\mathrm{OCH}_{3}, \mathrm{C}-2\right.$ or $\mathrm{C}-11), 4.13\left(\mathrm{~s} ; 2 \mathrm{H} ;-\mathrm{CH}_{2} ; \mathrm{H}-8\right), 6.03$ (s; $1 \mathrm{H}$ vinyl; $\left.\mathrm{H}-13\right), 6.60(\mathrm{~s} ; 1 \mathrm{H}$ arom; H-4), 6.62 (s; $1 \mathrm{H}$ arom; $\mathrm{H}-1$ or $\mathrm{H}-12), 6.63$ (s; $1 \mathrm{H}$ arom; H-9), 7.12 (s; $1 \mathrm{H}$ arom; H-1 or H-12).- UV: $\lambda \max (\log \varepsilon)=375$ (4.13), 343 (4.09), 285 (4.35), $263 \mathrm{~nm}$ (4.19).- MS: $\mathrm{m} / \mathrm{z}=353\left(81 \%, \mathrm{M}^{+}\right), 352\left(100,{ }^{*} 351.00\right.$ $\left.(\mathrm{M}-\mathrm{H})^{+}\right), 338\left(20,\left(\mathrm{M}-\mathrm{CH}_{3}\right)^{+}\right), 337\left(10,{ }^{*} 322.64\left(352-\mathrm{CH}_{3}\right)^{+-}\right), 336(21$, $\left.{ }^{*} 335.00(337-\mathrm{H})^{+}\right), 322(5), 308(7), 279(8), 192(18), 176.5\left(10, \mathrm{M}^{2+}\right)$.

b) Iminium-Salt, trifluoroacetate: $3.19\left(\mathrm{t} ; \mathrm{J}=7.8 \mathrm{~Hz} ; 2 \mathrm{H} ;-\mathrm{CH}_{2}-; \mathrm{H}-5\right)$, 3.88 (s; $\left.3 \mathrm{H} ;-\mathrm{OCH}_{3} ; \mathrm{C}-10\right), 3.89,3.98\left(\mathrm{~s} ; 6 \mathrm{H} ;-\mathrm{OCH}_{3} ; \mathrm{C}-2 / \mathrm{C}-11\right), 4.02$ (s; $\left.3 \mathrm{H} ;-\mathrm{OCH}_{3} ; \mathrm{C}-3\right), 4.14$ (t; J = 7.8 Hz; $\left.2 \mathrm{H} ;-\mathrm{CH}_{2}-\mathrm{H}-6\right), 4.47$ (s [broad]; $2 \mathrm{H}$; $\left.-\mathrm{CH}_{2}-; \mathrm{H}-13\right), 5.05\left(\mathrm{t} ; \mathrm{J}=3.8 \mathrm{~Hz} ; 2 \mathrm{H} ;-\mathrm{CH}_{2}-\mathrm{H}-8\right), 6.75(\mathrm{~s} ; 1 \mathrm{H}$ arom; $\mathrm{H}-4)$, 6.81 (s; $1 \mathrm{H}$ arom; $\mathrm{H}-1$ or $\mathrm{H}-12), 6.87(\mathrm{~s} ; 1 \mathrm{H}$ arom; $\mathrm{H}-4), 7.35$ (s; $1 \mathrm{H}$ arom; $\mathrm{H}-1$ or H-12).- UV (acetonitrile plus $\mathrm{HCl}): \lambda \max (\log \varepsilon)=341(4.41), 287$ (4.35), $239 \mathrm{~nm}$ (4.27).

\section{(士)-Xylopinine (16)}

( \pm )-Xylopinine (16) is prepared from enamine 15 according to Kiparissides ${ }^{11)}$.- Purification: $\mathrm{CC}\left(\mathrm{SiO}_{2}\right.$, EtOAc).- Yield: $70-80 \%$, yellow crystals, m.p. $161-163^{\circ} \mathrm{C}(\mathrm{EtOH})$, lit. $156-157^{\circ} \mathrm{C}^{11)}$.

\section{2,3,10,11-Tetramethoxyberbiniumiodide (17)}

$300 \mathrm{mg}( \pm)$-Xylopinine (16) (0.82 mmole) are dissolved in absol. $\mathrm{MeOH}$ $(25 \mathrm{ml})$ under $\mathrm{N}_{2}$. To the refluxing solution are added $0.64 \mathrm{~g} \mathrm{I}_{2}$ in $30 \mathrm{ml}$ absol. $\mathrm{MeOH}$ until the suspension turned brownish. After refluxing for 30 min $\mathrm{NaHSO}_{3}$-solution is added until a yellow colour remains. The yellow precipitate is washed with water and ether and dried.- Yield: $80-90 \%$, yellow crystals, m.p. $255^{\circ} \mathrm{C}$ (dec., EtOH/ $\left.\mathrm{H}_{2} \mathrm{O}\right)$, lit. $245^{\circ} \mathrm{C}(\mathrm{dec} \text {. })^{35)}$.

\section{2,3,10,11-Tetramethoxy-8H-dibenzo[a,g]quinolizin-8-one (18)}

$300 \mathrm{mg}$ 5,6-Dihydro-8-oxoberbine $3 \mathrm{f}$ are mixed thoroughly with $300 \mathrm{mg}$ of $\mathrm{Pd} / \mathrm{C}(10 \%)$ under $\mathrm{N}_{2}$ for $15 \mathrm{~min}$. The mixture is heated in an oil bath (bath temp. $220^{\circ} \mathrm{C}$ ) for $1 \mathrm{~h}$. After cooling the product is separated from the catalyst by extraction with $\mathrm{CH}_{2} \mathrm{Cl}_{2}$ and filtration. The org. layer is evaporated and dried.- Purification: $\mathrm{CC}\left(\mathrm{SiO}_{2}\right.$, EtOAc) or PTLC $\left(\mathrm{SiO}_{2}\right.$, ether).Yield: $80-90 \%$; yellow crystals, m.p. $192-194^{\circ} \mathrm{C}(\mathrm{EtOH})$, lit. 196$197^{\circ} \mathrm{C}^{36)}$. - IR ( $\left.\mathrm{KBr}\right): 1650(-\mathrm{CO}) \mathrm{cm}^{-1} .{ }^{1} \mathrm{H}-\mathrm{NMR}\left(\mathrm{CDCl}_{3}\right): \delta(\mathrm{ppm})=3.98$ $\left(\mathrm{s} ; 3 \mathrm{H} ;-\mathrm{OCH}_{3}\right), 4.03\left(\mathrm{~s} ; 6 \mathrm{H} ;-\mathrm{OCH}_{3}\right), 4.08\left(\mathrm{~s} ; 3 \mathrm{H} ;-\mathrm{OCH}_{3}\right), 6.37(\mathrm{~d} ; \mathrm{J}=7.5$ $\mathrm{Hz} ; 1 \mathrm{H} ; \mathrm{H}-5), 6.85,6.97,7.17,7.50,7.82(\mathrm{~s} ; 4 \mathrm{H}$ arom and $1 \mathrm{H}$ vinyl), 8.35 (d; J = 7.5 Hz, 1H; H-6).- UV: $\lambda \max (\log \varepsilon)=422$ (3.97), 398 (4.07), 376 (4.04), 293 (4.42), $261(4,41), 224 \mathrm{~nm}(4.47)$.

\section{0-Aza-5,6-dihydro-2,3-dimethoxy-8H-dibenzo[a,g]quinolizin-8-one(19)}

Prepared from 3,4-dihydro-6,7-dimethoxy-1-methyl-isoquinoline ${ }^{37)}$ and nicotinic acid chloride according to Len ${ }^{14)}$ - Yield: $40 \%$.- Yellow-orange crystals, m.p. $162-165^{\circ} \mathrm{C}(\mathrm{EtOH})$, lit. $169-172^{\circ} \mathrm{C}^{14)}$.

\section{Biological methods \\ MDA-MB 231 Human Breast Cancer Cells ${ }^{12)}$}

Cells were grown in $\mathrm{McC}$ Coy medium (Fa. Boehringer, Mannheim) supplemented with $10 \%$ newborn calf serum (NCS, Fa. Gibco), gentamicin (40 $\mu \mathrm{g} / \mathrm{ml})$ and $\mathrm{NaHCO}_{3}(2.2 \mathrm{~g} / \mathrm{l}, \mathrm{pH}=7.35)$. Cells were grown in a humidified incubator in $5 \% \mathrm{CO}_{2}$ at $37^{\circ} \mathrm{C}$ and harvested with $0.05 \%$ trypsine- $0.02 \%$ EDTA in $0.15 \mathrm{M} \mathrm{NaCl}$. At the beginning of the experiment the cell suspension is switched to 96 -holes mikrotitre dishes $(100 \mu \mathrm{l} / \mathrm{hole})$. After $2-3$ days of incubation at $37^{\circ} \mathrm{C}$ the medium is changed to substance-containing medium. Control holes (16/dish) are containing $0.1 \%$ of the pertinent solvent only. The starting cell density is determined by adding vinblastine in 18 holes. After further incubation ( 3 days) the medium is removed and gluta- 
raldehyde $(100 \mu \mathrm{l})$ in phosphated buffer saline (PBS) $(1 \%)$ is added for fixation. After $15 \mathrm{~min}$ the aldehyde is decanted and after $25 \mathrm{~min}$ the cells are colored with $100 \mu$ l of a crystal violet-solution $\left(0.02 \%\right.$ in $\left.\mathrm{H}_{2} \mathrm{O}\right)$. After this solution is decanted the cells are washed with $\mathrm{H}_{2} \mathrm{O}$ for a few times to remove unused staining. After addition of $100 \mu \mathrm{lEtOH}$ the dishes are shaken for 1 $h$. The optical density is determined in a microtitre dish-autoreader EL 309 (Bio-tek) at $578 \mathrm{~nm}$, the data are processed on an Olivetti M24-PC ${ }^{13}$.

\section{UV-Difference-Spectroscopy}

\section{a) Interaction with native DNA}

Calfthymus-DNA type I (Fa. Sigma) is dissolved in 0.1-M-Tris-NaClbuffer ( $\mathrm{pH} 7.4)$ at $4^{\circ} \mathrm{C}$. The concentration of the solution is about $6 \times 10^{-5}$ $\mathrm{M}$ (according to phosphorus). Test substances are dissolved in DMSO $\left(10^{-2}\right.$ $\mathrm{M}$ solution). Tandem quartz-cells (Fa. Helma) are used. Test- and reference-cuvette are containing the DNA-solution in one part, in the other part only buffer. $1 \mu \mathrm{l}$ of the substance-solution is added to the DNA in the test-cell and to the buffer in the reference-cell, respectively. The mixture is incubated for $2 \mathrm{~min}$ and after cautious stirring the extinction difference is determined between 550 and $230 \mathrm{~nm}$. A solution of ethidium bromide $\left(10^{-2}\right.$ $\mathrm{M}$ ) is used as positive control and in order to limit the volume of solvent 10 $x 1 \mu$ substance solution are added at the outmost. To determine a concentration dependence (linear increase of the plot) of the interaction between substance and DNA, the extinction is plotted versus the quotient from substance concentration and DNA-phosphorus concentration.

\section{b) Interaction with sonicated DNA}

The experiment is performed according to a). To destroy the DNA-structure the DNA-solution (see above) is sonicated for $10 \mathrm{~min}$ at room temp. For evaluation of the spectra identical concentrations of substances are compared (native/sonicated DNA).

\section{c) Interaction with (non-)phosphorylated DNA-increments}

The experiment is performed according to a), but a solution of (non-) phosphorylated DNA-increments $\left(10^{-2} \mathrm{M}\right)$ is used instead of the DNA solution.

\section{Fluorescence Spectroscopy}

To determine a DNA-induced shift in the fluorescence spectra of our substances we measured the spectra with $5 \mu$ l substance solution $\left(10^{-2}\right.$ M/DMF) in phosphated buffer saline and of $5 \mu \mathrm{l}$ substance solution $+5 \mu \mathrm{l}$ DNA solution (ca. $4.6 \times 10^{-5} \mathrm{M}$, according to phosphorus) in PBS between 600 and $330 \mathrm{~nm}$, respectively.- Excitement wavelength: $265 \mathrm{~nm}$; excitement bandpass: $5 \mathrm{~nm}$; emission bandpass: $5 \mathrm{~nm}$; scan speed: $600 \mathrm{~nm} / \mathrm{min}$.

\section{Displacement of Ethidium bromide}

To get sufficient fluorescence intensity at the beginning of the titration we used the ratio $[\mathrm{DNA}=$ mole phosphorus $] /[$ mole ethidium bromide $]=$ 2.0. The concentration of the DNA solution (in 0.1-M-Tris-NaCl-buffer, ph 7.4) was $4.6 \times 10^{-5} \mathrm{M}$ (according to phosphorus), the concentration of ethidium bromide $10^{-2} \mathrm{M}$ (in DMF), actinomycin $\mathrm{D}\left(10^{-2} \mathrm{M} / \mathrm{DMF}\right)$ was used as a positive control. In the experiments aliquots of the test substance solutions are added to the ethidium bromide-DNA solution, and after mixing the quenching of fluorescence intensity is determined.- Excitement wavelength: $546 \mathrm{~nm}$; emission wavelength: $590 \mathrm{~nm}$; excitement bandpass: $5 \mathrm{~nm}$; emission bandpass: $5 \mathrm{~nm}$.

\section{Viscosity Experiments}

For this experiment an Ostwald-viscosimeter (No. I) is used, the concentration of the DNA solution (in 0.1-M-Tris-NaCl-buffer, $\mathrm{pH}$ 7.4) was $4.6 \mathrm{x}$ $10^{-5} \mathrm{M}$ (according to phosphorus). The concentration of the test substances was $10^{-2} \mathrm{M}$ (in DMF). In order to find the apparatus constant the sinking time in the buffer was determined, which was equal to that of water. The apparatus constant is calculated according to the following usual formula:

$$
\gamma=\frac{\eta}{\rho}=\mathrm{k} \cdot \mathrm{t}
$$

$\gamma=$ kinematic viscosity, $\eta=$ dynamic viscosity, $\rho=$ density, $k=$ apparatus constant, $\mathrm{t}=$ sinking time.

As basic value for the sinking time the DNA-solution was measured. By addition of aliquots from the substance solution to the DNA-solution in the viscosimeter the ratio between substance- and DNA concentration was raised from 0.01 to 0.1 with compensation of the solvent effects. From this experiment the corrected time for the measurements is resulting:

Corrected time $=t_{D N A}+D M F-t_{D N A}$

The corrected time is substracted from the sinking time of the substance solutions, the resulting value is the corrected sinking time for the substances. Now it is possible to calculate the kinematic viscosity $\gamma$.

$$
\gamma=\frac{\eta}{\rho}=\mathrm{k} \cdot \mathrm{t},
$$

$\gamma=$ kinematic viscosity, $\eta=$ dynamic viscosity, $\rho=$ density, $k=$ apparatus constant, $\mathbf{t}^{\prime}=$ corrected sinking time.

\section{References}

1 K.Y. Zee-Cheng and C.C. Cheng, J. Pharm. Sci. 61, 967 (1972) and lit. cited therein.

2 A.K. Krey and F.E. Hahn, Science 166, 755 (1969).

3 W. Schneider and K. Schroeter, Ber. Dtsch. Chem. Ges. 53, 1459 (1920); W. Schneider and O. Böger, ibid. 54, 2021 (1921). - W. Wiegrebe, Dtsch. Apoth. Ztg. 106, 1546 (1966).

4 J.F. Stambach and L. Jung, Tetrahedron 4I, 169 (1985).

5 R.D. Haworth and W.H. Perkin jun., J. Chem. Soc. 1926, 1769.

6 M.A. Haimova, V.I. Ognyanov, and N.M. Mollov, Synthesis 1980, 845 .

7 R.V. Davies, B. Iddon, and H. Suschitzky, J. Chem. Soc. Perkin I 1978, 180.

8 J. Finkelstein and A. Brossi, J. Heterocycl. Chem. 4, 315 (1967).

9 A. Bruggink and A. McKillop, Tetrahedron 31, 2607 (1975) and Angew. Chemie 86, 349 (1974).

10 J. Gadamer, Arch. Pharm. 243, 35 (1905).

11 Z. Kiparissides, R.H. Fichtner, J. Poplawski, B.C. Nalliah, and D.B. MacLean, Can. J. Chem. 58, 2770 (1980).

12 E. v. Angerer, J. Prekajac, and M. Berger, Eur. J. Cancer Clin. Oncol. 21,531 (1985).

13 S. Erber, H. Birnböck, and E. v. Angerer, J. Med. Chem. 1990 (in press).

14 G.R. Lenz, J. Heterocycl. Chem. 16, 433 (1979).

15 W.D. Wilson, A.N. Gough, J.J. Doyle, and M.W. Davidson, J. Med. Chem. 19, 1261 (1976).

16 B. Gaugain, J. Barbet, N. Capelle, B.P. Roques, and J.-B. LePecq, Biochemistry 17, 5078 (1978).

17 J.-B. LePecq and C. Paoletti, J. Mol. Biol. 27, 87 (1967).

18 J.D. McGhee and P.H. v. Hippel, J. Mol. Biol. 86, 469 (1974).

19 C. Weimar, S. von Angerer, A. Mannschreck, and W. Wiegrebe, in preparation.

20 W. Müller and D.M. Crothers, J. Mol. Biol. 35, 251 (1968).

21 D. Pelaprat, R. Oberlin, I. LeGuen, and B.P. Roques, J. Med. Chem. 23,1330 (1980).

22 J.M. Saucier, B. Festy, and J.-B. LePecq, Biochimie 53, 973 (1971).

23 G.R. Lenz, J. Org. Chem. 39, 2839 (1974).

24 A. Pictet and T.Q. Chou, Ber. Dtsch. Chem. Ges. 49, 374 (1916).

25 A. Brossi, J. Würsch, and O. Schnider, Chimia 12, 114 (1958).

26 J.F. Ajao and C.W. Bird, J. Heterocycl. Chem. 22, 329 (1985).

27 T. Kametani, T. Ohsawa, M. Ihara, and K. Fukumoto, Chem. Pharm. Bull. 26, 1922 (1978). 
28 A.H. Jackson, G.W. Stewart, G.A. Charnock, and J.A. Martin, J. Chem. Soc. Perkin I 1974, 1911.

29 L. Helfer, Helv. Chim. Acta 7, 945 (1924).

30 K.T. Potts and R. Robinson, J. Chem. Soc. 1955, 2682.

31 A. Horeau and J. Jacques, Bull. Soc. Chim. France 1948, 53.

32 S.N. Rastogi, J.S. Bindra, and N. Anand, Ind. J. Chem. 9, 1175 (1971); C.A. $76,113018 \mathrm{z}(1972)$.
33 A. Pictet and A. Gams, Ber. Dtsch. Chem. Ges. 44, 2036 (1911).

34 R.D. Haworth, J.B. Koepfli, and W.H. Perkin jun., J. Chem. Soc. 1927, 548.

35 G.R. Lenz, J. Org. Chem. 42, 1117 (1977)

36 N.T.L.Q. Thuan and J. Gardent, Compt. Rend. Acad. Sci. Paris Serie C 267, 1340 (1968).

37 E. Späth and N. Polgar, Monatsh. Chem. 137, 1142 (1928). [Ph828] 